\title{
Use Balanced Scorecard (BSC) Perspectives in the Service Sector: A Case Study on the Jordanian Private Universities
}

\author{
Atef Aqeel Al- Bawab ${ }^{1}$ \\ ${ }^{1}$ Irbid National University, Jordan \\ Correspondence: Atef Aqeel Al-Bawab, Irbid National University, Irbid, Jordan. \\ Received: June 21, 2017 \\ Accepted: July 10, 2017 Online Published: July 21, 2017 \\ doi:10.5539/ibr.v10n8p192 \\ URL: https://doi.org/10.5539/ibr.v10n8p192
}

\begin{abstract}
This study aimed to identify on how to use Balanced Scorecard (BSC) perspectives in the service sector in general and in the Jordanian private universities in particular. The study was designed questionnaire to achieve the study objective, the questionnaire was distributed to(48), has recovered from (42) identify the rate of recovery was $(87.5 \%)$, and after analyzing the data and test hypothesis using analysis methods through the program (SPSS) we found many of the results was the most important: There is using of the Balanced Scorecard (BSC) perspectives in the Jordanian private universities partially, The researcher recommends that The universities hve to use all the perspectives of Balanced Scorecard (BSC) in the work as well as follow-up students after graduation in order to give the Promotional League. and The university has to work feedback about the services provided to the students.
\end{abstract}

Keywords: Balanced Scorecard(BSC), The Jordanian Private Universities, Jordan

\section{Introduction}

The Education was in the Hashemite Kingdom of Jordan, one of the priorities of the Jordanian state since the inception of the emirate in 1921, and continued attention to this aspect so that schools spread across in many area in Jordan, and in 1964 established the Jordan University, then spread across the public universities. After that issued laws that allow to establish the private universities, to contribute in the educational process and also to contribute in the development of society economically and socially, and that many of the arguments, including the inability of the public universities to accommodate all successful students in the public university, and to reduce the leakage of funds when citizens send their sons to study outside, and it was necessary to preserve on the capital invested because it contribute in the national income.

This study came to identify how use apply the (BSC) approach in the Jordanian private universities, to increase investor confidence in the success of those universities.

\subsection{Problem of the Study}

This study revolves around the extent of the use Balanced Scorecard (BSC) perspectives in the service sector in general and the Jordanian private universities in particular, where we can show the problem by asking the following question:

- Do the Balanced Scorecard (BSC) perspectives is used in the service sector in general and the Jordanian private universities in particular? To answer this question, it could be the following questions about the perspectives of Balanced Scorecard (BSC):

$\circ$ Do the financial perspective is used in the Jordanian private universities?

○ Do the customers (students) perspective is used in the Jordanian private universities?

- Do the internal business process perspective is used in the Jordanian private universities?

$\circ$ Do the learning and growth perspective is used in the Jordanian private universities?

\subsection{Importance of the Study}

The importance of this study through the interest offered by the Balanced Scorecard (BSC) to evaluate and improve performance, where there was much talk in academic departments, and among the economic sectors that seek to achieve the highest levels of quality, through the application of many of the standards offered by the 
professional organizations, and where that the activity of the private Jordanian universities is originally an economic activity designed to profit in addition to educational and societal goals, from here it was necessary to discuss this issue especially now that customers of this sector is the university students, who are subject to the instructions and standards imposed by the Ministry of Higher Education and scientific research to achieve quality education requirements in Jordan. Applying managerial concepts such as the Balanced Scorecard approach to educational settings has been shown to be an effective way of solving educational management problems. (e.g. Riasi \& Asadzadeh, 2015, 2016, Rowley, 2000).

\subsection{Objectives of the Study}

This study aims to find out how to use Balanced Scorecard (BSC) perspectives in the service sector in general and the Jordanian private universities in particular, and to achieve this goal, the study aimed to achieve the following sub-objectives:

- Knowledge of the extent for the using of the financial perspective as one of the Balanced Scorecard (BSC) in the Jordanian private universities.

- Knowledge of the extent for the using of the customers (students) perspective as one of the Balanced Scorecard (BSC) in the Jordanian private universities.

- Knowledge of the extent for the using of the internal business process perspective as one of the Balanced Scorecard (BSC) in the Jordanian private universities.

- Knowledge of the extent for the using of the learning and growth perspective as one of the Balanced Scorecard (BSC) in the Jordanian private universities.

\section{Literature Review}

There are many studies that have addressed the issue of the Balanced Scorecard (BSC) as the following:

1) Rajaee \& etc. study 2016, entitled Application of Balanced Scorecard (BSC) in Evaluating the Performance of Health Care Providers: A Re view. This study, chosed the articles aiming to assess the health care and hospital using BSC. Then compared with the present study, and then the related studies were briefly mentioned. The results of this study showed that combining models is a way for assessing function and increasing the satisfaction and commitment. And the balanced scorecard is recommended as a model that can help increase efficiency and better evaluation of the performance.

2) Saad \& Daraghma study 2016, entitled Using of the Balanced Scorecard for Performance Evaluation: Empirical Evidence from the Listed Corporations in the Palestine Exchange (PEX). The study aimed to test the extent to which the listed Palestinian corporations in the Palestine Exchange (PEX) are using the four perspectives of the Balanced Scorecard (BSC) in evaluating the performance. In order to achieve the previous objective, this paper uses a questionnaire to investigate the opinions of the financial managers of the listed corporations in the PEX. In relation to the results of the distributed questionnaire forms, there are 37 questionnaire forms, where 32 questionnaire forms were returned (32 out of 37) which presents (86.5\%). This study employs the descriptive statistics in order to state the outcomes. However, the findings of this paper state the following points: (1) The financial managers rely on the financial and customer perspectives for evaluating the performance of the listed corporations in the PEX. (2) The Palestinian listed corporations do not rely on the learning and growth indicators for measuring the performance. (3) The Palestinian listed corporations do not rely on the business process indicators for measuring the performance. (4) This paper concludes that the listed corporations in Palestine do not rely on the BSC indicators for measuring the performance in a correct and complete way.

3) Jarerah study, 2014, entitled the extent of the evaluation of performance by using the dimensions of the balance score card of the shareholding companies for food industries in Jordan - a field study. The nutritional industries sector in Jordan has grown and de veloped in recent years due to the large investments in this field and the use of modern industrial techniques, in addition to paying a great deal of attention to the safety and quality which are the two cornerstones for food manufacture and production. So this study has been conducted to reveal that the evaluation of performance by using Balanced Score card (BSC) in shareholding companies for food industries in Jordan with its four perspectives (financial perspective, customer perspective, internal business process perspective, innovation and learning perspective) has become necessary in these companies for integrating in a perfect strategic planning to maintain the present global competitive ability.

To examine the extent of the evaluation of performance by using the dimensions of balanced score card in these companies, a questionnaire of 24 items has been designed and distributed on four hypotheses each one of them 
handled one perspective of the four perspectives of BSC.

The study has concluded that the shareholding companies for food industries in Jordan use financial and nonfinancial performance measures to evaluate their performance and these measures are related to financial perspective ,customer perspective, internal business process perspective, innovation and learning perspective with referring to that the perfect use of this card has been amorphous.

4) Bernard M., Alexandru S., and Jeannette. C. study, 2012, entitled "Time Evolution Analysis And Forecast Of Key Performance Indicators In A Balanced Scorecard". This study aimed to develop a comprehensive framework linking the Balanced Scorecard model with the entrance to the structural balance (structural) (SEM) to support modern strategic indicators of financial and non-financial concept so as to achieve better management and control common performance and accordingly comprises the several basic concepts of the proposed framework, including: over the performance evaluation using the emphasis on key performance indicators and its relation with the actual objectives of the company. Converting the current strategy to model cause and effect can be directed and controlled by using key performance indicators, and therefore, this model works to achieve integration and better communication and long-term management and be able to show politics long circuit predictive of the company.

5) Lucianetti Lorenzo study 2010, entitled "The impact of the strategy maps on balanced scorecard performance". The purpose of this paper is to examine the balanced scorecard (BSC) adoption experience amongst organisations in connection with the strategy map design. Using survey data from managers of 91 Italian organisations the paper seeks to verify whether the development of the strategy maps affects BSC performance and in turn business results. Evidence shows that benefits coming from BSC usage are considerably lower for those organisations who have not implemented this model in connection with the design of an appropriate strategy map. The implications for managers appears very interesting given that the lack of development of strategy maps related to the BSC model seems to not only substantially decrease its perceived expected benefits, but also decreases the organisation's overall competitiveness.

6) Barbara Bigliardi and Eleonora Bottani study, 2010, entitled "Performance measurement in the food supply chain: a balanced Scorecard approach". This study aimed to develop a set of key performance indicators embodied in the Balanced Scorecard (BSC) in order to measure the performance of companies in the food industry. I have been to validate the Balanced Scorecard developed by a group of specialists who work in the food industry has been applying the model to the two companies that operated in the food industry expert model, and proven results of the study detailed most of the proposed key performance indicators of the health of the Balanced Scorecard, which can be considered suitable for use model as a tool in the food industry companies. The study also showed the concept of education and growth represents an exception in this regard was observed some different results.

7) Al-Khatatneh Waheed R. and Al-Sa'aydeh Mansour I., study (2009), entitled "The level of Awareness of Jordanian Industrial Public Companies' Managers of the Significance of the Non-Financial Perspectives (Measures) of the Balanced Scorecards (BSC) in Evaluating The Performance of their Companies". The objective of this study is to measure the level of awareness of Jordanian industrial public companies' managers of the significance of the non-financial perspectives (measures) of the Balanced Scorecards (BSC) in evaluating the performance of their companies.

For this purpose, a 38-item questionnaire was designed to enable the researches to test the three main hypothesis of the study.

The first main hypothesis, however, consists of three sub-hypotheses; each one focuses on a single non-financial perspective of the BSC, namely the customer, the internal process and the learning and development perspectives.

Using the appropriate statistical tests (the one sample t-test and the ANOVAF test), the main results of the study turn out to be:

A. Jordanian industrial public companies' managers (individually) are highly aware of the significance of the non-financial measures of the Balanced Scorecard when evaluating the performance of their companies.

B. Industrial companies' managers do not overall realize the importance of using the Balanced Scorecard model overall when evaluating the performance of their companies.

C. There are no differences in awareness of the significance of the non-financial perspectives of the BSC related to managers' age, experience or academic qualifications. 
Based on the above results of the study, several recommendations were developed; the main one is that it is necessary to adopt the proposed Balanced Scorecard model by the managers of Jordanian industrial public companies in order to tie together the strategic plans, performance evaluation techniques and goals of the company.

8) Ax \& Bjornenak study, (2005), entitled “Bundling and Diffusion of Management According in Sweden”. This study was to determine the prevalence of balanced goals between Swedish companies card model, and through the test the use of more than one model of the card, and the researcher suggested that changes and accounting developments are the result of clarification and use operations, and deploy innovations of modern management accounting ideas and different methods help the process of using renovations, and benefit from, and to suit the specific region or company situation and balanced Scorecard (BSC (as a method of accounting administrative interview can be published in Sweden with modifications to it.

\subsection{What Distinguishes this Study?}

Previous studies have focused on the following:

- Evaluate of the performance of the food industry public shareholding companies in Jordan using the Balanced Scorecard dimensions Rating (financial perspective, customer perspective, internal operations perspective, and learning and growth perspective.) in the food industry public shareholding companies in Jordan.

- The extent of the ability to the managers in the Jordanian public shareholding companies to use the standards for the non-financial card balanced evaluation of performance goals.

- Develop a set of key performance indicators embodied in the Balanced Scorecard (BSC) in order to measure the performance of companies in the food industry.

The current study has come to focus on the extent of use of the service sector of the Balanced Score Card (BSC) in general and the Jordanian private uni versities in particular. The current study looking at all perspectives of the Balanced Scorecard (BSC) (financial perspective, the customers (students) perspective, internal business processes perspective, and learning and growth perspective).

\subsection{Hypothesis of the Study}

H0: No use of the Balanced Scorecard (BSC) perspectives in the Jordanian private universities. To test this hypothesis we structured the sub-hypothesis as the following:

$\mathbf{H O}_{1}$ : No use of the financial perspective as one of the Balanced Scorecard perspectives in the Jordanian private universities.

$\mathbf{H O}_{2}$ : No use of the customers (students) perspective as one of the Balanced Scorecard perspectives in the Jordanian private universities.

H0 $_{3}$ : No use of the internal operations perspective as one of the Balanced Scorecard perspectives in the Jordanian private universities.

$\mathbf{H O}_{4}$ : No use of the learning and growth perspective as one of the Balanced Scorecard perspectives in the Jordanian private universities.

\subsection{Theoretical Framework}

There is a trend in the companies to adopt modern methods of performance evaluation, called the methods of measurement and e valuation of the comprehensive performance, these methods are based on the use of financial and non-financial measures to evaluate the performance (Abu Fideh, 2006).

Kaplan and Norton identified the (BSC) as a sequential series of goals and standards to each depends on the others and is supported by, and what is follow that of actions and measures. (Kaplan and Norton, 1996).

Jackson and Sawyers indicated to the (BSC) that is a methodology to measure the performance uses a set of financial and non-financial measures related success factors important to the company, integrates financial and non-financial performance measures, and this approach helps the management to keep the successful factors of the company. (Jackson and Sawyers, 2001).

But Gering and keith identified the (BSC) as a tool used to transport and deliver strategy of a company to the units and administrative levels to measure the effect on those units, and also Their use so as to ensure the achievement of targeted results, including support from the strength of the facility and its competitive position by providing a tool for the implementation of the strategy and accountability for the targeted results. (Gering and Keith, 2000). 


\subsubsection{The Balanced Scorcad (Kaplan And Atkinson, 1998)}

First: Financial perspective

The Balanced Scorecard retains the financial perspective since financial measures are valuable in summarizing the readily measurable economic consequence of actions already taken. Financial performance measures indicate whether the company's strategy, implementation, and execution are contributing to bottom-line improvement. Financial objectives typically are related to profitability-measured, for example, by operating income, return-on-capital employed, or more recently, economic value added. Alternative financial objectives can be rapid sales growth or generation of cash flow.

To succeed financially, how should we appear to our shareholders?

\begin{tabular}{|c|c|c|c|}
\hline \multirow{2}{*}{ To succeed financially, how should we appear to our shareholders? } & \multicolumn{3}{|l|}{ FINANCIAL } \\
\hline & Objectives & Targets & Initiatives \\
\hline
\end{tabular}

Customer Perspective

In the customer perspective of the Balanced Scorecard, managers identify the customers and market segments in which the business unit will compete and the measures of the business unit's performance in these targeted segments. The customer perspective typically includes several core generic measures of the successful outcomes from a well-formulated and implemented strategy. The core outcome measures include customer satisfaction, customer retention, new customer acquisition, customer profitability, and market and account share in targeted segments.

\section{Financial Objectives}

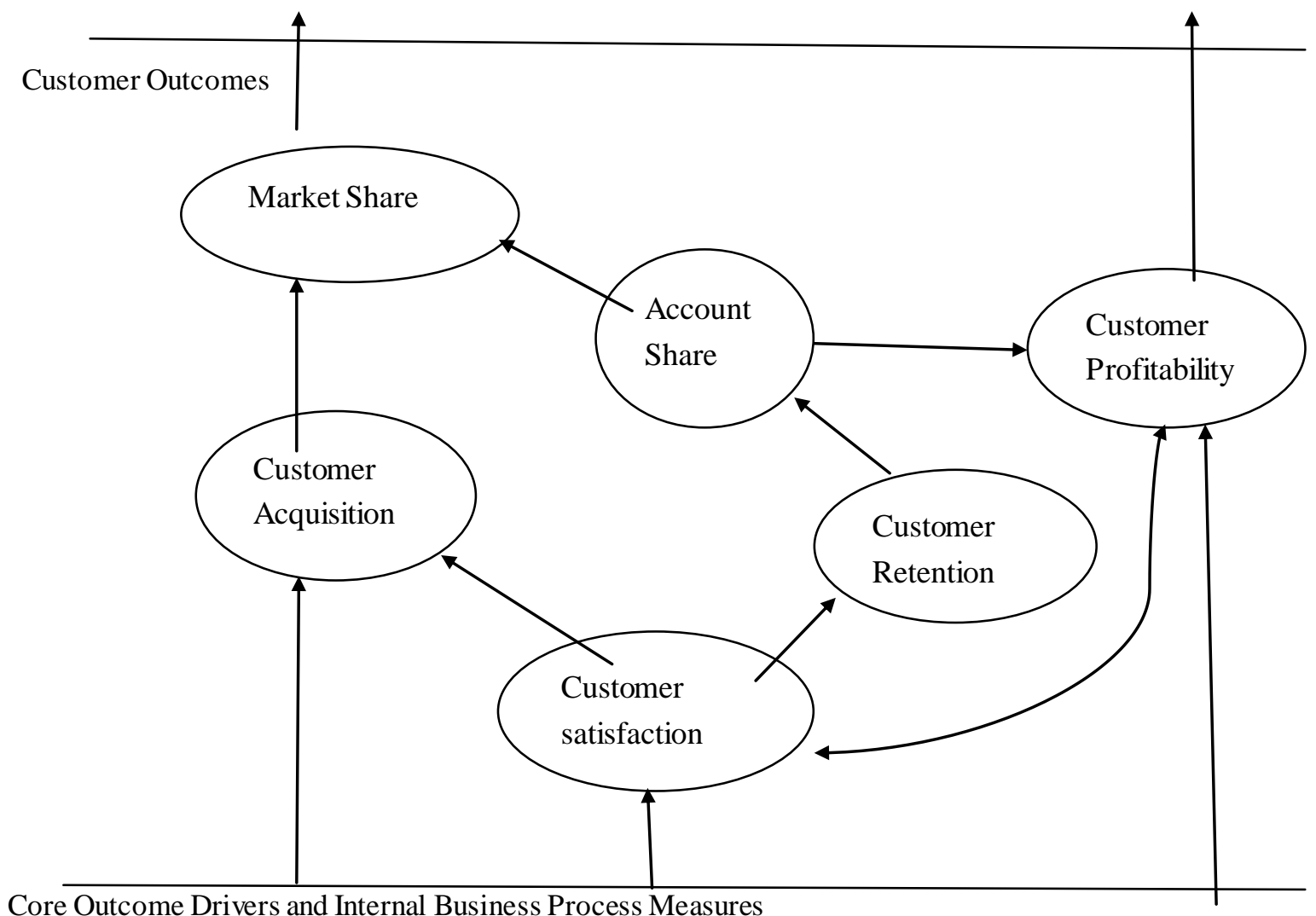

Core Outcome Drivers and Internal Business Process Measures

Third: Internal Business process Perspective

The internal business process measures are focused on the internal process that will have the greatest impact on customer satisfaction and achieving the organization's financial objectives.

Fourth: Learning and Growth Perspective

The fourth Balanced Scorecard perspective, learning and growth, identifies the infrastructure that the organization must build to create long-term growth and improvement. The customer and internal business process perspective identify the factors most critical for current and future success. Business are unlikely to be able to meet their long-term targets for customers and internal process using today's technologies and 
capabilities. Also, intense global competition requires that companies continually improve their capabilities for delivering value to customers and shareholders.

It has been presented of the perspectives for the Balanced Scorecard (BSC), we note that, there are a financial and non-financial measures, which helps in the relationship between operational and strategic directions for the company, because the linking between the strategic objectives and goals on short-term, which affects positively on the financial perspective of the company.

The determination of performance standards is one of the parts to achieve and implement of the strategy (Simons, 2000) by two sides:

First: determine the acts and activities are required which are located in the lower level of the performance standards.

Second: set goals and identify the plans that are located in the top level of the performance standards.

So these measures are considered a link between goals and plans from side, and on the other side between the achieved activities and which is necessary to achieve these goals and plans.

Kaplan and Norton suggest four steps to implement the Balanced Scorecard (BSC):(Kaplan and Norton, 1996).

1. Clarify and translate the vision and strategy for the company.

2. Linking the strategic objectives of the company with the goals of the departments in the company through the organizational structure.

3. Set the plans and objectives for the administrative departments in the company.

4. Make feedback for the strategy of the company.

\section{Statistical Anal ysis and Hypothesis Testing}

\subsection{The Study Population and Sample}

The population of the study consists of accountants and financial workers in the Jordanian private universities of (20) University according to the annual statistical report of higher education for the year 2014, a number of (48) were distributed randomly to this community, the researcher retrieved (42) questionnaire, representing (87.5\%) of the population which is acceptable and valid for statistical analysis ratio. Annex No. (1) Shows the study population according to the annual statistical report of higher education until the year 2014.

Table 1. The names of the universities and the establish year of each one

\begin{tabular}{clc}
\hline No. & \multicolumn{1}{c}{ University Name } & Year established \\
\hline 1 & Jordan Applied University College of Hotel and Tourism Sciences & 1980 \\
2 & Philadelphia University. & 1989 \\
3 & Jordan Academy of Music. & 1989 \\
4 & Arab Academy for Banking and & 1989 \\
& Financial Sciences. & 1990 \\
5 & Amman National University. & 1990 \\
6 & Zarka Private University. & 1990 \\
7 & Al-Zaytoonah Jordanian private University. & 1991 \\
8 & Sciences Applied private University. & 1991 \\
9 & Al-Isra Private University. & 1991 \\
10 & Petra University. & 1991 \\
11 & Princess Sumaya University for Technology. & 1992 \\
12 & Jerash University. & 1992 \\
13 & Irbid National University. & 1993 \\
14 & Educational Sciences Faculty. & 1997 \\
15 & Amman Arab University. & 2002 \\
16 & Arab Open University. & 2005 \\
17 & Middle East University for Higher Studies. & 2005 \\
18 & Jadara University for Higher Studies. & 2008 \\
19 & Ajloun National Private University. & 2009 \\
\hline
\end{tabular}

Source: The Hashemite Kingdom of Jordan, the Ministry of Higher Education and Scientific Research, 2014.

\subsection{The Study Tool}

The questionnaire is a tool that relied upon to test the hypotheses of the study, the questionnaire consisted of two main sections:

Section I: special demographic characteristics of the study population in terms of age and educational qualification, scientific specialization, function, and the number of years of experience. 
Section II: contained questions regarding the testing of the hypotheses of the study, Likert scale was adopted to answer specific questions regarding the study variables, were it consisted of five degrees, as in the following Table 2:

Table 2. The Table Shows the Degrees Distributed on the Questions of the Questionnaire

\begin{tabular}{cccccc}
\hline & Strongly agree & Agree & Neutral & Disagree & $\begin{array}{c}\text { Strongly } \\
\text { Disagree }\end{array}$ \\
\hline Degrees & 5 & 4 & 3 & 2 & 1 \\
\hline
\end{tabular}

The means and standard deviations were also calculated and handled according to the following order (2.33 and below low), (2.34 - 3.66 Mean), (3.67 or above is high). And this measure has been calculated according to the following equation:

(The upper limit (5) - the minimum (1)) / Number of categories $(3)=(1.333)$. Then add this to the final output of each category. As shown in Table No. 2 (following): (Sekaran,2010).

\subsection{Statistical Methods Used}

The data analysis was done using statistical data analysis software (SPSS), and the following statistical methods were used:

A - Cronbach's alpha test to test the reliability of the study tool.

B - Descriptive statistics through the use of the following: Frequencies, Percentages, Means, The standard deviations.

C - One-Sample t-test, to test Hypotheses of the study and test whether there is a statistically significant difference between the arithmetic mean of the hypotheses and the mean measurement tool, and thus judge the sample opinion about assumptions.

\subsection{Testing the Validity and Reliability of the Study Tool}

The arbitration of the questionnaire was done by a number of professors, academics and a number of workers in financial departments in the Jordanian private universities to ensure harmony and objectiveness of the study questions for foreign credibility, with respect to the internal credibility, the Cronbach's Alpha test was selected to measure the degree of internal consistency, as shown in Table 3 that the reliability coefficient value for each study axes of (0.760) with a high value of the ratio accepted the (0.60), demonstrating the reliability of the study tool and the high internal consistency between its paragraphs.

Table 3. Cronbach's Alpha coefficient of stability of the study

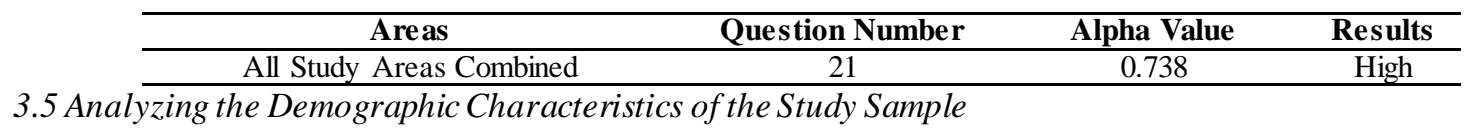

Table 4 relates to the demographic characteristics of the study sample in terms of: job nature, age, years of experience, qualification, and academic specialization. The questionnaires showed that retrieved the demographic characteristics of the study sample were as follows: 
Table 4. Table shows The Demographic Characteristics of The Study Sample

\begin{tabular}{|c|c|c|c|}
\hline Description & Category & Frequency & Percentage \\
\hline \multirow{4}{*}{ Age } & Less than 30 & 5 & $12 \%$ \\
\hline & $31-40$ Years & 17 & $40 \%$ \\
\hline & $41-50$ Years & 15 & $36 \%$ \\
\hline & 51 years old and more & 5 & $12 \%$ \\
\hline \multirow{7}{*}{ Years of Experience } & Total & 42 & $\% 100$ \\
\hline & Left than 5 years & 8 & $19 \%$ \\
\hline & $6-10$ years & 13 & $31 \%$ \\
\hline & $11-15$ years & 18 & $43 \%$ \\
\hline & More than 15 years & 3 & $7 \%$ \\
\hline & Total & 42 & $\% 100$ \\
\hline & Less than bachelors & 5 & $12 \%$ \\
\hline \multirow{4}{*}{ Qualification } & Bachelor's degree & 30 & $70 \%$ \\
\hline & Master's degree & 7 & $18 \%$ \\
\hline & PHD & 0 & $0 \%$ \\
\hline & Total & 42 & $\% 100$ \\
\hline \multirow{7}{*}{ Job Nature } & Financial Manager & 5 & $12 \%$ \\
\hline & Assistance of Financial Manager & 3 & $7 \%$ \\
\hline & Internal Auditor & 7 & $16 \%$ \\
\hline & Accountant & 16 & $38 \%$ \\
\hline & Accountant of Students & 10 & $25 \%$ \\
\hline & Other Financial Job & 1 & $2 \%$ \\
\hline & Total & 42 & $\% 100$ \\
\hline
\end{tabular}

Table 4 shows that the highest percentage in the age featured group (31-40 years) achieved a ratio of (40\%), the age group fit to this work is category that is consistent with years of experience, which was the highest in the category (11-15 years) occupied proportion (43\%), and this enhances the credibility of the response, but with regard to qualification feature, those who got bachelor's degree category of the highest percentages in terms of $(70 \%)$, because the majority of financial workers are trying to get professional certifications more than academic degrees, regarding of the job nature, the accountant's function category reaching (38\%), and this is normal because most of the workers in financial circles they Accountants and are engaged in the profession of specialized accounting, while other functions are occupied by percentages as low as shown abo ve and this gives credence to the responses.

\subsection{Main Study Hypothesis Testing}

H0: There is no commitment to the requirements of corporate governance to raise the performance of the financial departments in the Jordanian private universities.

To test the hypothesis of the study will there will be sub-hypotheses relating to the requirements of the Corporate Governance test as the following:

\section{The First Sub-Hypothesis Test:}

$\mathbf{H O}_{1}$ : No use of the financial perspective as one of the Balanced Scorecard perspectives in the Jordanian private universities.

To test this hypothesis has been collected data analysis and the results were as in Table 5:

Table 5. Means and Standard Deviations of the Paragraphs of The First Area

\begin{tabular}{clccc}
\hline No. & \multicolumn{1}{c}{ Paragraphs } & Mean & $\begin{array}{c}\text { Standard } \\
\text { Deviation }\end{array}$ & $\begin{array}{c}\text { Degree of } \\
\text { Agreement }\end{array}$ \\
\hline 1. & $\begin{array}{l}\text { The university is working to increase operating revenue by } \\
\text { increasing the number of students and through raising the capacity }\end{array}$ & 4.4286 & 0.50087 & High \\
2. $\quad \begin{array}{l}\text { The university is always working to attract students from outside } \\
\text { Jordan. }\end{array}$ & 4.1905 & 0.39744 & High \\
& $\begin{array}{l}\text { The university is working to improve the cost structure (review the } \\
\text { cost of the student). }\end{array}$ & 3.6429 & 0.57685 & Mean \\
4. $\quad \begin{array}{l}\text { The University uses existing assets by high efficiently. } \\
\quad \text { Paragraphs (1- 4) related to the financial perspective. }\end{array}$ & 3.6905 & 0.60438 & High \\
High
\end{tabular}

It can be seen from Table (5) that the degree of approval was high for most paragraphs - exception paragraph No. 3 was 3.6429- of the domain ranging from (3.6905 - 4.4286) and a standard deviations that ranged between (0.60438 - 0.50087), and with an arithmetic mean in total of 3.9881 representing a high degree of approval, while the standard deviations stated a degree of difference between the answers which means a difference of opinion and thus the reliability of the answers. The first sub-hypothesis was tested using the T test, sample results were as in the following table: 
Table 6. One Sample T-test to Test TheFirst Sub-Hypothesis

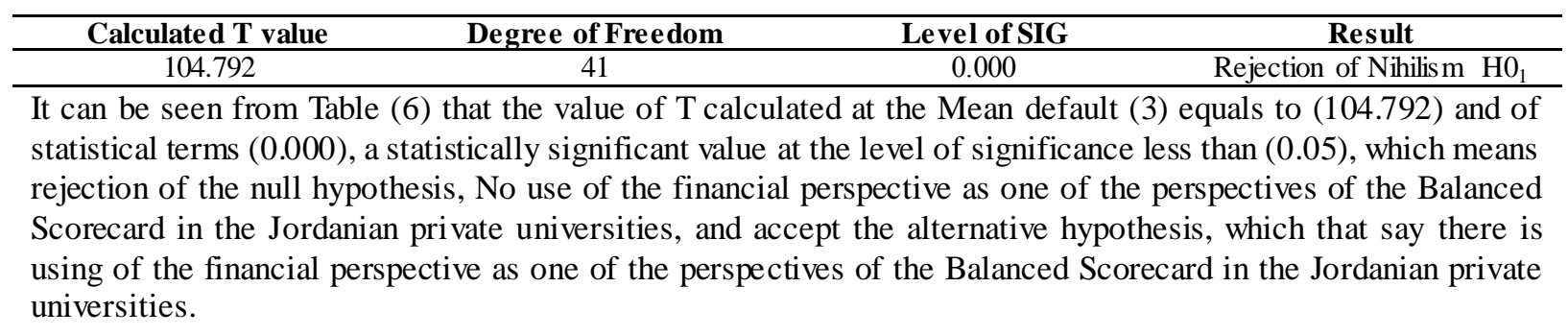

\section{The Second Sub-Hypothesis Test}

$\mathrm{HO}_{2}$ : No use of the customers (students) perspective as one of the Balanced Scorecard perspectives in the Jordanian private universities.

To test this hypothesis collected data was analyzed and the results were as in Table 7:

Table 7. Means and Standard Deviations of the Paragraphs of the Second Area

\begin{tabular}{clccc}
\hline No. & \multicolumn{1}{c}{ Paragraphs } & Mean & $\begin{array}{c}\text { Standard } \\
\text { Deviation }\end{array}$ & $\begin{array}{c}\text { Degree of } \\
\text { Agreement }\end{array}$ \\
\hline 5 & $\begin{array}{l}\text { The university is working to provide students by supplies } \\
\text { (extracurricular activities Supplies) periodically. }\end{array}$ & 3.04776 & 0.93580 & Low \\
6 & $\begin{array}{l}\text { The university is working to follow up on complaints of students } \\
\text { through different ways. }\end{array}$ & 2.5238 & 0.67130 & Low \\
7 & $\begin{array}{l}\text { The university is working on a follow-up students after graduation in } \\
\text { order to give the Promotional League. }\end{array}$ & 1.4048 & 0.70051 & Low \\
8 & $\begin{array}{l}\text { The university is constantly working to attractive the largest possible } \\
\text { number of new students. }\end{array}$ & 3.0238 & 2.97541 & Low \\
9 & $\begin{array}{l}\text { The university works feedback about the services provided to the } \\
\text { students. } \\
\text { The university studies the needs of community to open new } \\
\text { specializations. }\end{array}$ Paragraphs (5- 10) related to the customer perspective. & 2.8571 & 0.47223 & Low \\
& Low & 2.5712 & 0.53773 & Low \\
\hline
\end{tabular}

It can be seen from Table (7) that the degree of approval was low for all paragraphs of the domain ranging from $(1.4048-3.04776)$ and the standard deviations ranged between $(0.47223-2.97541)$, and with an arithmetic mean of the total 2.5712 represents the degree of low approval, while the standard de viations stated degrees of difference between the answers which means a difference of opinion and thus the reliability of the answers. The second sub-hypothesis was tested using T test, sample results were as in the following table:

Table 8. One Sample T-test to Test The Second Sub-Hypothesis

\begin{tabular}{|c|c|c|c|c|}
\hline \multirow{2}{*}{$\begin{array}{c}\text { Calculated T value } \\
30.988\end{array}$} & Degree of Freedom & $\frac{\text { Level of SIG. }}{0000}$ & \multicolumn{2}{|c|}{ Result } \\
\hline & 30.988 & 0.000 & \multicolumn{2}{|c|}{ Accept of Nihilism H02 } \\
\hline \multicolumn{5}{|c|}{$\begin{array}{l}\text { It can be seen from Table ( } 8) \text { that the value of T calculated at the Mean default ( } 3 \text { ) equals to (30.988) and the } \\
\text { Means all of the paragraphs was } 2.5712 \text { and this is less than the Mean default, so we will accept the null } \\
\text { hypothesis, No use of the customers perspective as one of the perspectives of the Balanced Scorecard in the } \\
\text { Jordanian private universities. }\end{array}$} \\
\hline \multicolumn{5}{|c|}{ The Third sub-hypothesis Test: } \\
\hline \multicolumn{5}{|c|}{$\begin{array}{l}\mathrm{H}_{3} \text { : No use of the internal operations perspective as one of the Balanced Scorecard perspectives in the Jordanian } \\
\text { private uni versities. To test this hypothesis, collected data was analyzed and the results were as in Table (9) as } \\
\text { following: }\end{array}$} \\
\hline \multicolumn{5}{|c|}{ Table 9. Means and Standard Deviations of the Paragraphs of the Third Area } \\
\hline No. & Paragraphs & Mean & Deviation & $\begin{array}{c}\text { Degree of } \\
\text { Agreement }\end{array}$ \\
\hline 11 & $\begin{array}{l}\text { The university implements the best standards to maintain the quality } \\
\text { of services provided to students. }\end{array}$ & 3.1190 & 0.63255 & Low \\
\hline 12 & $\begin{array}{l}\text { The university interests in develop of the administrative work systems } \\
\text { and the use of information technology. }\end{array}$ & 2.0714 & 0.94721 & Low \\
\hline 13 & $\begin{array}{l}\text { There is cooperation between the deanships colleges and departments } \\
\text { of various departments in the university (such as the Department of } \\
\text { Registration and financial Department,). }\end{array}$ & 4.2619 & 0.44500 & High \\
\hline 14 & $\begin{array}{l}\text { There is an amount in the budget of the university for research and } \\
\text { development. }\end{array}$ & 1.4524 & 0.88902 & Low \\
\hline & The University solves the problems that appear on the educational & 1.8095 & 0.70670 & Low \\
\hline & Average & 2.5429 & 0.52132 & Low \\
\hline
\end{tabular}


It can be seen from Table (9) that the degree of approval was low for all paragraphs of the domain ranging from $(1.4524-3.1190)$ and the standard deviations ranged between $(0.88902-0.63255)$, exception paragraph No. (13) the mean was (4.2619) and the standard deviations (0.44500), with an arithmetic mean of the total 2.5712 represents the degree of low approval, while the standard deviations stated degrees of difference between the answers which means a difference of opinion and thus the reliability of the answers. The third sub-hypothesis was tested using $\mathrm{T}$ test sample results were as in the following table:

The third sub-hypothesis was tested using T test, sample results were as in the following table:

Table 10. One Sample T-test to Test the Third Sub-Hypothesis

\begin{tabular}{|c|c|c|c|c|}
\hline & Degree of Freedom & \multirow{2}{*}{$\frac{\text { Level of SIG }}{0.000}$} & \multicolumn{2}{|c|}{ Result } \\
\hline & 41 & & Accep & Nihilism H03 \\
\hline \multicolumn{5}{|c|}{$\begin{array}{l}\text { It can be seen from Table (10) that the value of T calculated at the Mean default ( } 3) \text { equals to }(31.611) \text { and the } \\
\text { Means all of the paragraphs was } 2.5429 \text { and this is less than the Mean default, so we will accept the null } \\
\text { hypothesis, No use of the internal operations perspective as one of the Balanced Scorecard perspectives in the } \\
\text { Jordanian private universities. }\end{array}$} \\
\hline \multicolumn{5}{|c|}{ The Forth sub-hypothesis Test: } \\
\hline \multicolumn{5}{|c|}{$\begin{array}{l}\mathrm{H}_{3} \text { : No use of the learning and growth perspective as one of the Balanced Scorecard perspectives in the } \\
\text { Jordanian private universities. To test this hypothesis, collected data was analyzed and the results were as in } \\
\text { Table } 10 \text { as following: }\end{array}$} \\
\hline \multicolumn{5}{|c|}{ Table 10. Means and Standard Deviations of the Paragraphs of the Forth Area } \\
\hline No. & Paragraphs & Mean & Deviation & $\begin{array}{c}\text { Degree of } \\
\text { Agreement }\end{array}$ \\
\hline 16 & $\begin{array}{l}\text { The university is working to improve the technology used by updating } \\
\text { hardware and software. }\end{array}$ & 2.3571 & 0.57685 & Low \\
\hline 17 & The University train new workers. & 2.2857 & 0.70834 & Low \\
\hline 18 & The University train old workers to update their information. & 2.0000 & 0.79633 & Low \\
\hline 19 & $\begin{array}{l}\text { The University offers incentives and rewards for innovation and } \\
\text { development. }\end{array}$ & 2.0714 & 0.40682 & Low \\
\hline 21 & $\begin{array}{l}\text { The university is working to develop new educational services to } \\
\text { provide to the local community during a specified period. }\end{array}$ & 2.2857 & 0.55373 & Low \\
\hline \multirow[t]{2}{*}{21} & The university is interested morale of employees, both administrators & 2.1190 & 0.70546 & Low \\
\hline & 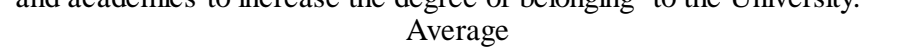 & 2.1862 & 0.39676 & Low \\
\hline
\end{tabular}

It can be seen from Table (10) that the degree of approval was low for all paragraphs of the domain ranging from $(2.0000-2.3571)$ and the standard de viations ranged between $(0.40682-0.79633)$, with an arithmetic mean of the total 2.1862 represents the degree of low approval, while the standard de viations stated degrees of difference between the answers which means a difference of opinion and thus the reliability of the answers. The forth sub-hypothesis was tested using $\mathrm{T}$ test sample results were as in the following table

Table 11. One Sample T-test to Test the Third Sub-Hypothesis

\begin{tabular}{cccc}
\hline Calculated T value & Degree of Freedom & Level of SIG & Result \\
\hline 35.709 & 41 & 0.000 & Accept of Nihilism H04 \\
\hline It
\end{tabular}

It can be seen from Table (11) that the value of T calculated at the Mean default (3) equals to (35.709) and the Means all of the paragraphs was 2.1862 and this is less than the Mean default, so we will accept the null hypothesis, No use of the learning and growth perspective as one of the Balanced Scorecard perspectives in the Jordanian private universities.

\section{Conclusions and Recommendations}

In light of the data analysis and hypothesis testing, the study reached to many of the conclusions and recommendations as the following:

\section{First: Conclusions:}

1. There is using of the Balanced Scorecard (BSC) perspectives in the Jordanian private universities partially, regarding of the financial perspective.

2. There is no using of the customers (students) perspective as one of the Balanced Scorecard perspectives in the Jordanian private universities. like this The university is not working on a follow-up students after graduation in order to give the Promotional League. also The university do not works feedback about the services provided to the students. 
3. There is no using of the internal operations perspective as one of the Balanced Scorecard perspectives in the Jordanian private universities. Like, The university interests in develop of the administrative work systems and the use of information technology. Also the university dose not interests in develop of the administrative work systems and the use of information technology, solves the problems that appear on the educational services provided to students, and There is not an amount in the budget of the university for research and development.

4. There is no using of the learning and growth perspective as one of the Balanced Scorecard perspectives in the Jordanian private universities. Like, The University dose not train old workers to update their information, also offers incentives and rewards for innovation and development.

\section{Second: Recommendations:}

1. The university has to work on a follow-up students after graduation in order to give the Promotional League.

2. The university has to work feedback about the services provided to the students.

3. The university has to interest in develop of the administrative work systems and the use of information technology.

4. The university has to interest in solve the problems that appear on the educational services provided to students.

5. The university has to put an amount in the budget of the university for research and development.

\section{References}

Abu, F., \& Marwan, M. A. (2006). Develop a balance system to measure the strategic performance in the Islamic banks. (Unpublished doctoral dissertation), The Arab Academy for Banking and Financial Sciences, Jordan.

Al-Khatatneh, W. R., \& Al-Sa'aydeh, M. I. (2009), The level of Awareness of Jordanian Industrial Public Companies' Managers of the Significance of the Non-Financial Perspectives (Measures) of the Balanced Scorecards (BSC) in Evaluating The Performance of their Companies. Jordan Journal of Business Administrative, University of Jordan, Amman, 5(1).

Ax, C., \& Bjornenak, T. (2005). Bundling and Diffusion of Management According in Sweden. Management Accounting Research, 16, 1-20. https://doi.org/10.1016/j.mar.2004.12.002

Barbara, B., \& Eleonora, B. (2010). Performance Measurement in the food supply chain; a balanced Scorecard approach. Emerald Group Publishing Limited, 28(5), 249.

Bernard, M., Alexandru, S., \& Jeannette. C. (2012). Time Evolution Analysis And Forecast Of Key Performance Indicators In A Balanced Scorecard. Global Conference on Business and Finance Proceeding, 7(2), 568.

Gering, M., \& Keith, R. (2000). Central beating' Financial Management, June, 32-33.

Jackson, S., \& Sawyers, R. (2001). Managerial Accounting A focus on Decision making, Harcourt College publishers.

Jarerah, T. S. (2014). The extent of the evaluation of performance by using the dimensions of the balance score card of the shareholding companies for food industries in Jordan - a field study." An International Refereed Research Journal "DIRASAT” University of Jordan, Amman, 41(2), July 2014.

Kaplan, R. S., \& Atkinson, A. (1998). Advanced Management Accounting, Brd Edition, Prentice Hall, New Jersey.

Kaplan, R. S., \& Norton, D. P. (1996). Using the Balanced Scorecard as a Strategic Management System. Harvard Business Review, 74(10), 75-86.

Kaplan, R. S., \& Norton, D. P. (2001). Transforming the Balanced Scorecard from performance measurement to strategic management. Accounting Horizons, 15(1), 87-104. https://doi.org/10.2308/acch.2001.15.1.87

Lucianetti, L. (2010). The impact of the strategy maps on balanced scorecard performance". Int. J. Business Performance Management. Faculty of Economics, Department of Business Studies, University of Chieti and Pescara, 12(1). https://doi.org/10.1504/IJBPM.2010.036040

Rajaee, R., Fard, S. M. A. M., Farzam, A., Ghamari, F., Kalhor, R., \& Gholami, S. (2016). Application of Balanced Scorecard (BSC) in Evaluating the Performance of Health Care Providers: A Review. International Journal on Recent and Innovation Trends in Computing and Communication, 4(3).

Riasi, A., \& Asadzadeh, N. (2015). The relationship between principals' reward power and their conflict 
management styles based on Thomas-Kilmann conflict mode instrument. Management Science Ltters, 5(6), 611-618. https://doi.org/10.5267/j.msl.2015.4.004

Riasi, A., \& Asadzadeh, N. (2016). How coercive and legitimate power relate to different conflict management styles: a case study of Birjand high schools. Journal of studies in Education, 6(1), 147-159. https://doi.org/10.5296/jse.v6i1.8946

Rowley, J. (2000). Is higher education ready for knowledge management? International Journal Of Educational Management, 14(7), 325-333. https://doi.org/10.1108/09513540010378978

Saad, R. I., Daraghma, Z., \& Mohammad, A. (2016). Using of the Balanced Scorecard for Performance Evaluation: Empirical Evidence from the Listed Corporations in the Palestine Exchange (PEX). International Journal of Business and Management, Canadian Center of Science and Education, 11(3). https://doi.org/10.5539/ijbm.v11n3p215

Simons, R. (2000). Performance Measurement and Control System for Implementing Strategy, New Jersey, Englewood: Prentice-Hall.

The Hashemite Kingdom of Jordan, the Ministry of Higher Education and Scientific Research. (2014).

\section{Copyrights}

Copyright for this article is retained by the author(s), with first publication rights granted to the journal.

This is an open-access article distributed under the terms and conditions of the Creative Commons Attribution license (http://creativecommons.org/licenses/by/4.0/). 